\title{
Radiological investigation of natural carbonated spring waters from Eastern Carpathians, Romania
}

\author{
R.-Cs. Begy ${ }^{1,2} \cdot$ C.-F. Savin ${ }^{1} \cdot$ D.-K. Süle ${ }^{1} \cdot$ M. Nuhanovic ${ }^{3} \cdot$ E. Giagias ${ }^{1} \cdot$ T. Kovács $^{4}$ (D)
}

Received: 16 November 2021 / Accepted: 7 January 2022 / Published online: 8 February 2022

(c) The Author(s) 2022

\begin{abstract}
The current study presents a radiological water-quality assessment on 64 spring water samples from four Romanian counties. The study area is abundant in $\mathrm{CO}_{2}$-rich spring waters consumed by locals and tourists. Gross alpha activities ranged between $21 \pm 2$ and $7530 \pm 658 \mathrm{mBq} \mathrm{L}^{-1}$, with $27 \%$ of the samples exceeding the WHO threshold. Gross beta values ranged from $40 \pm 2$ to $5520 \pm 430 \mathrm{mBq} \mathrm{L}^{-1}$, with $29 \%$ exceeding the recommended values. Radionuclide activities fluctuated between $0.6 \pm 0.08$ and $81 \pm 6 \mathrm{~Bq} \mathrm{~L}^{-1}$ for ${ }^{222} \mathrm{Rn}, 15 \pm 2$ to $1154 \pm 112 \mathrm{mBq} \mathrm{L}^{-1}$ for ${ }^{226} \mathrm{Ra}$, and from $18 \pm 2$ to $64 \pm 5 \mathrm{mBq} \mathrm{L}^{-1}$ for ${ }^{210} \mathrm{Po}$. The annual effective doses attributed to radium varied between 0.002 and $0.23 \mathrm{mSv} \mathrm{yr}^{-1}$.
\end{abstract}

Keywords Gross alpha $\cdot$ Gross beta $\cdot$ Potable spring waters $\cdot$ Eastern Carpathians

\section{Introduction}

Water is an essential resource and a basic human right. In order to be suitable for human consumption, it has to meet quality standards for microbial, chemical and radiological properties. Radionuclides are naturally present in water, resulting mainly from processes of dissolution, leaching and desorption of the surrounding geological environment (rocks and sediments) [23]. The primary alpha-emitting natural radionuclides present in water are ${ }^{224} \mathrm{Ra},{ }^{226} \mathrm{Ra}$ and ${ }^{210} \mathrm{Po}$. Gross beta activities are mainly attributed to ${ }^{228} \mathrm{Ra},{ }^{210} \mathrm{~Pb}$ and ${ }^{40} \mathrm{~K}$ [7]. Water is a factor that can potentially increase the internal exposure to natural radiation [37], and for this reason, national and international guidelines were issued to ensure the safety of drinking water [9, 13, 21, 38]. World Health Organization (WHO) [38] recommends a threshold value of $0.5 \mathrm{~Bq} \mathrm{~L}^{-1}$ for gross alpha activity and $1.0 \mathrm{~Bq} \mathrm{~L}^{-1}$

T. Kovács

kt@almos.uni-pannon.hu

1 Faculty of Environmental Science and Engineering, "BabesBolyai" University, 400084 Cluj-Napoca, Romania

2 Interdisciplinary Research Institute On Bio-Nano-Sciences, "Babes-Bolyai" University, 400271 Cluj-Napoca, Romania

3 Department of Chemistry, University of Sarajevo, 71000 Sarajevo, Bosnia and Herzegovina

4 Institute of Radiochemistry and Radioecology, University of Pannonia, H-8200 Veszprém, Hungary for gross beta activity, for water to be considered radiologically safe for consumption. These values were established in regard to the Individual Dose Criterion (IDC) adopted, of $0.1 \mathrm{mSv} \mathrm{yr}^{-1}$ for a $2 \mathrm{~L}$ daily water consumption. Romanian law 301/2015 was issued considering the same IDC, and establishes a guidance level of $0.1 \mathrm{~Bq} \mathrm{~L}^{-1}$ for gross alpha, and $1.0 \mathrm{~Bq} \mathrm{~L}^{-1}$ for gross beta activity.

In Romania, more than 2000 natural spring waters are documented [3, 30], many of which are located in the Eastern Carpathians. This region is characterized by the proximity of the Neogene Călimani-Gurghiu-Harghita and Oaş-Gutâi volcanic ranges. Therefore, manifestations of post-volcanism in the area are leading to the occurrence of sparkling, $\mathrm{CO}_{2}$-rich mineral waters $[18,34]$. Thousands of local inhabitants are consuming raw water directly from the local springs on a daily basis, as their main source of drinking water or for medicinal purposes $[6,10]$. The water resources in this region are also accounting for $45 \%$ of the bottled mineral waters from Romania [10]. Beside drinking, the mineral waters are often associated with balneological practices [17] and is an important factor for tourism in the Eastern Carpathians [8]. Therefore, determining the radioactivity levels of these water resources is important for public health safety, and allows for the assessment of radiation exposure resulted from water ingestion. Few studies on the radiological quality of drinking water were conducted in the Eastern Carpathians, Romania [4, 24, 25]. Most studies are 
focusing mainly on ${ }^{222} \mathrm{Rn}$ and ${ }^{226} \mathrm{Ra}$ radionuclides, but the present-day state of knowledge in the area remains scarce.

The aim of the present study is to perform a radiological survey on 64 natural carbonated water samples collected from four counties in Romania, namely Covasna, Harghita, Bistrița-Năsăud and Maramureș, located in close proximity to the Eastern Carpathians and the Neogene volcanic ranges that it hosts. Water physico-chemical parameters (temperature, $\mathrm{pH}$, redox potential, electrical conductivity, total dissolved solids (TDS) and salinity) were measured for each sample. Gross alpha and beta activity measurements, along with specific radionuclide determinations $\left({ }^{210} \mathrm{Po},{ }^{222} \mathrm{Rn}\right.$, ${ }^{226} \mathrm{Ra},{ }^{40} \mathrm{~K}$ ) were conducted and the results compared with the guidance levels for radioactivity in drinking water, established by WHO [38] and the national law [21]. The annual effective doses attributed to ${ }^{226} \mathrm{Ra}$ were calculated to assess the exposure to internal radiation.

\section{Materials and methods}

\section{Study site}

Sixty-four water samples were collected from sparkling mineral springs in four counties in Romania (Fig. 1). The first area includes Covasna and Harghita counties (32 samples labeled as CVHR), which are in the proximity of the Călimani-Gurghiu-Harghita volcanic range, and subjected to the post-volcanic manifestations associated with it. The second area, represented by Bistrița-Năsăud and Maramureș counties (32 samples labeled as BNMM), is located nearby the Oaş-Gutâi volcanic range. The samples were collected in $2 \mathrm{~L}$ plastic containers and acidified with $65 \%$ nitric acid $\left(\mathrm{HNO}_{3}\right)$, to avoid the adsorption losses of radionuclides on the container walls. At the time of sampling, water physico-chemical parameters (temperature, $\mathrm{pH}$, redox potential, electrical conductivity, TDS and salinity) were measured in $50 \mathrm{ml}$ beakers using an XS-PC5 multiparameter.

\section{Gross alpha/beta specific activity measurements}

For gross alpha and beta activity measurements, 11 of each sample was evaporated to dryness on a hot plate $\left(<85^{\circ} \mathrm{C}\right)$ without boiling. Subsequently, $0.2 \mathrm{~g}$ of the resulted residual material was dissolved with $3 \mathrm{ml} 3 \mathrm{M} \mathrm{HCl}$, and mixed with $15 \mathrm{ml}$ GoldStar Quanta scintillator cocktail in a plastic $20 \mathrm{ml}$ vial. The samples were then measured using a TRICARB 2300 TR Liquid Scintillation Counter with a 65\% efficiency for alpha and $85 \%$ for beta activity (tSIE $=479$ ), a minimum detectable activity (MDA) of $25 \mathrm{mBq} \mathrm{L}^{-1}$ and a measurement time of 21,600 s. The calibration was performed using a ${ }^{210} \mathrm{~Pb}$ standard in equilibrium with its successors, ${ }^{210} \mathrm{Bi}$ and ${ }^{210} \mathrm{Po}$, purchased from the Czech Methodology Institute. The resulting values are representing the total activity of the sample (alpha and beta), as TriCarb 2300 does not allow separation of impulses according to their origin. Gross alpha activities were determined by alpha counting, $0.1 \mathrm{~g}$ of the residual was milled and transferred to $45 \mathrm{~mm}$ diameter aluminum discs, ensuring the distribution of the mass. The discs were then covered with silver activated zinc sulphide
Fig. 1 Location of the water samples collected from carbonated springs in four counties in Romania, along with the local geology of the Eastern Carpathians

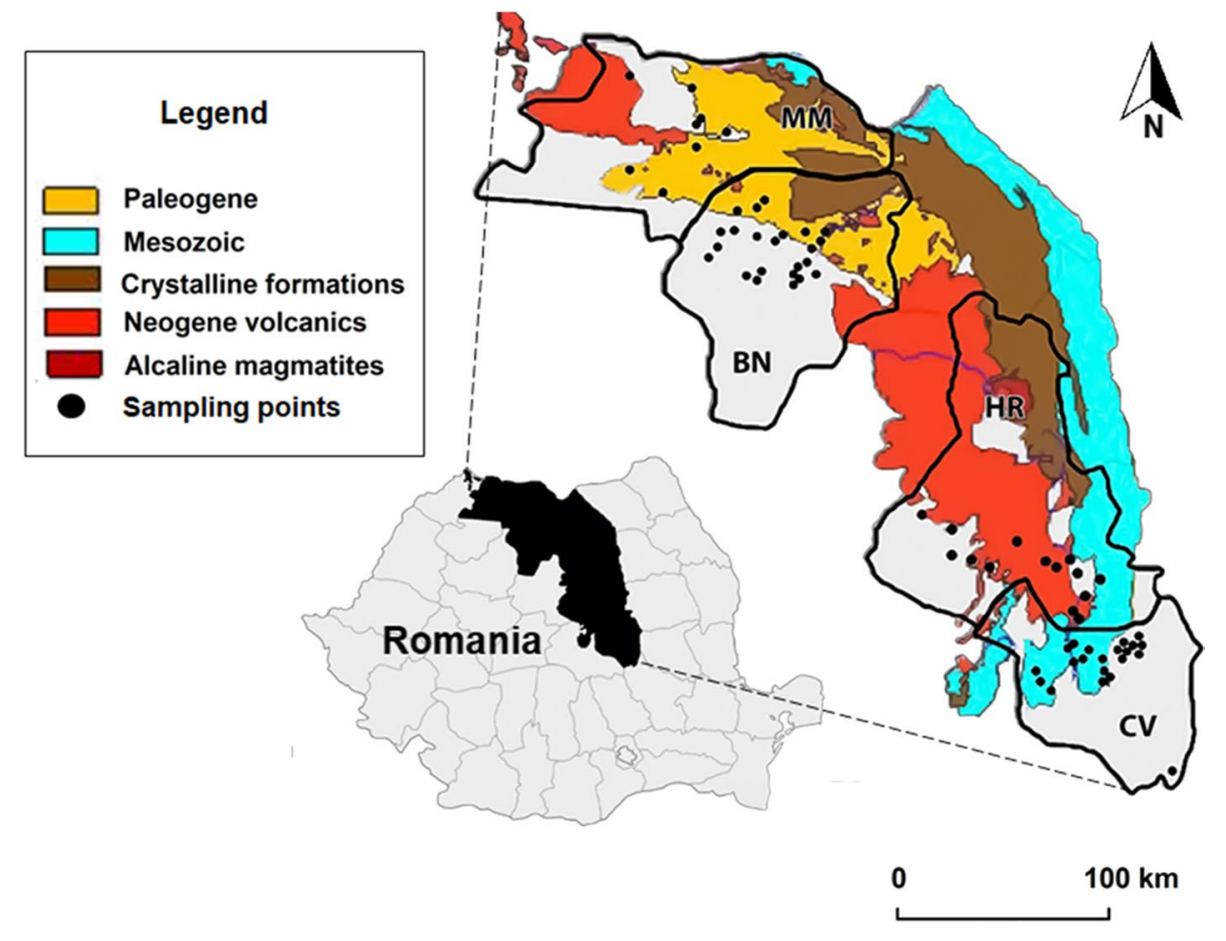


$(\mathrm{ZnS}(\mathrm{Ag}))$ sheets for alpha particle detection and were measured using an MEV NP-420 alpha counting system, for $10,000 \mathrm{~s}$. The calibration was performed using a ${ }^{209} \mathrm{Po}$ for a sample density of $25 \mathrm{mg} / \mathrm{cm}^{2}$. The minimum detectable activity for gross alpha activity was $20 \mathrm{mBq} \mathrm{L}^{-1}$. Gross beta activities were achieved by subtracting gross alpha from the total activity of the sample, previously measured by LSC.

\section{Radionuclide-specific measurements}

\section{Radon ( $\left.{ }^{222} \mathrm{Rn}\right)$ specific activity measurements}

The ${ }^{222} \mathrm{Rn}$ activity measurements were carried out by Liquid Scintillation Counting (LSC) technique [16]. The method involves adding $10 \mathrm{ml}$ of water, at the time of sampling, to $10 \mathrm{ml}$ mineral oil scintillator cocktail (ProScint Rn A/B) in a $20 \mathrm{ml}$ glass vial using a plastic syringe, after which the vial was sealed and shaken vigorously. The samples were then set aside for a minimum of $3 \mathrm{~h}$ to allow for the ingrowth of the short-lived progenies of ${ }^{222} \mathrm{Rn}[22,33]$. The measurements were carried out using a TRICARB 2300 TR Liquid Scintillation Counter calibrated with a standard NIST RaCl solution with an activity of $6 \mathrm{~Bq} \mathrm{~L}^{-1}$, dissolved in water. The MDA was $0.3 \mathrm{~Bq} \mathrm{~L}^{-1}$ and the measurement time $10,800 \mathrm{~s}$.

\section{Radium ( $\left.{ }^{226} \mathrm{Ra}\right)$ specific activity measurements}

The ${ }^{226} \mathrm{Ra}$ activity analysis procedure is based on the liquid scintillation technique, ${ }^{226} \mathrm{Ra}$ is determined through ${ }^{222} \mathrm{Rn}$ and its progenies, which are extracted by the scintillation cocktail from the water phase. In this regard, one liter of each sample was acidified with $65 \%$ nitric acid $\left(\mathrm{HNO}_{3}\right)$, and concentrated at least ten folds, in order to reach a lower detection limit, by gentle evaporation on a hot plate, at a temperature of $\leq 85{ }^{\circ} \mathrm{C}$. To avoid the occurrence of precipitation during the pre-concentration phase, all salts were converted in nitrates, which have a high solubility in water. Furthermore, $10 \mathrm{ml}$ of the pre-concentrated sample were transferred in a polyethylene vial, and $10 \mathrm{ml}$ scintillation cocktail (ProScint Rn A/B) were added. The vials were then stored in the dark at a constant temperature $\left(16^{\circ} \mathrm{C}\right)$, for 30 days, to allow for the ${ }^{222} \mathrm{Rn}$ ingrowth period. After the secular equilibrium between ${ }^{226} \mathrm{Ra}$ and ${ }^{222} \mathrm{Rn}$ was established, the samples were measured using a TRICARB 2300 TR Liquid Scintillation Counter, calibrated with a standard NIST $\mathrm{RaCl}$ solution, with an MDA of $20 \mathrm{mBq} \mathrm{L}^{-1}$, and a measurement time of $10,800 \mathrm{~s}$.

\section{Polonium $\left({ }^{210} \mathrm{Po}\right)$ specific activity measurements}

For ${ }^{210} \mathrm{Po}$ activity measurements, residue of samples that exceeded a gross alpha activity of $0.5 \mathrm{~Bq} \mathrm{~L}^{-1}$ was subjected to acidic digestion. To each sample, $0.3 \mathrm{~mL}\left(100 \mathrm{~Bq} \cdot \mathrm{mL}^{-1}\right)$
${ }^{209} \mathrm{Po}$ tracer was added. The samples were treated with $\mathrm{HNO}_{3}$ and $\mathrm{HCl}$. Subsequently, they were brought to $100 \mathrm{ml}$ using distilled water, the $\mathrm{pH}$ was adjusted in the $0.1-0.3$ range and the samples were left on a hot plate $\left(<85^{\circ} \mathrm{C}\right)$ for three hours to allow for the spontaneous deposition of ${ }^{210} \mathrm{Po}$ on high nickel content stainless steel discs [5]. The discs were than analyzed using an ORTEC SOLOIST Alpha Spectrometer System with Ultra ENS-U900 detectors and an active surface of $900 \mathrm{~mm}^{2}$ with a resolution greater than $29 \mathrm{keV}$, calibrated using a ${ }^{209} \mathrm{Po}$ standard solution. The minimum detectable activity for ${ }^{210} \mathrm{Po}$ was $15 \mathrm{mBq} \mathrm{L}^{-1}$.

\section{Potassium $\left({ }^{40} \mathrm{~K}\right)$ activity measurements}

The activity of ${ }^{40} \mathrm{~K}$ was measured for $1 \mathrm{~g}$ of dry residue from each sample using a Well-type High-Purity Germanium (HPGe) Gamma Spectrometric System (ORTEC GWL-12015 detector with a resolution of $2.08 \mathrm{keV}$ for $1.33 \mathrm{MeV}^{60} \mathrm{Co}$ and $1.1 \mathrm{keV}$ for $122 \mathrm{keV}{ }^{57} \mathrm{Co}$ gamma lines). The detector was calibrated with a Merck $\mathrm{KCl}$ solution, and has an MDA of $250 \mathrm{mBq} \mathrm{L}{ }^{-1}$. The specific activity of ${ }^{40} \mathrm{~K}$ was determined from its $1460.7 \mathrm{keV}$ gamma-ray lines after a measurement time greater than $120,000 \mathrm{~s}$. Spectrum acquisition was performed using the MAESTRO multi-channel analyzer software.

\section{Annual effective dose calculation}

The annual effective dose (AED) was calculated for ${ }^{226} \mathrm{Ra}$ activities from each sample, using the following equation [29]:

$\mathrm{AED}_{\mathrm{Ra}-226}=\Lambda_{\mathrm{Ra}-226} \cdot \mathrm{IRw} \cdot \mathrm{CF}$

where: $\mathrm{AED}_{\mathrm{Ra}-226}$ stands for ${ }^{226} \mathrm{Ra}$ Annual Effective Dose $\left(\mathrm{mSv} \mathrm{yr}^{-1}\right)$.

$\Lambda_{\text {Ra-226 }}$ stands for ${ }^{226} \mathrm{Ra}$ activity in the sample $\left(\mathrm{mBq} \mathrm{L}^{-1}\right)$.

IRw stands for the annual ingested volume of drinkingwater $\left(\mathrm{L} \mathrm{yr}^{-1}\right)$.

$\mathrm{CF}$ stands for the dose coefficient $\left(\mathrm{Sv} \mathrm{Bq}^{-1}\right)$.

The dose coefficient value of $2.8 \times 10^{-7} \mathrm{~Sv} \mathrm{~Bq}^{-1}$ as well as the IRw value of $730 \mathrm{~L} \mathrm{yr}^{-1}$ were extracted from Romanian law 301/2015 [21].

\section{Results and discussions}

\section{Water physico-chemical parameters measured values}

The measured values for water physico-chemical parameters at the time of sampling (temperature, $\mathrm{pH}$, conductivity, oxidation-reduction potential (ORP), TDS and salinity) in the 
studied area are presented in Table 1. Temperature ranged between 11.7 and $25{ }^{\circ} \mathrm{C} ; \mathrm{pH}$ values ranged between 1.71 and 8.18; ORP values were in the -56.7 to $296 \mathrm{mV}$ interval; conductivity values were between 252 and 10,560 $\mu \mathrm{S}$; TDS ranged from 178.5 to $7500 \mathrm{ppm}$, and salinity between 56.7 and $5850 \mathrm{mg} \mathrm{L}^{-1}$.

\section{Specific activity measured values}

The specific activity values of gross alpha and beta along with ${ }^{222} \mathrm{Rn},{ }^{226} \mathrm{Ra}$ and ${ }^{210} \mathrm{Po}$ radionuclides are presented in Table 2. WHO, 2017 and the national law 301/2015 are both stating that initial determinations of gross alpha and beta activities are required as the first step in assessing radiological safety of drinking water. Furthermore, if any guidance level for these activities is exceeded, specific determinations of radionuclides have to be followed. In the present study, gross alpha and beta, as well as ${ }^{222} \mathrm{Rn}$ and

${ }^{226} \mathrm{Ra}$ determinations were carried out for the whole set of samples. Subsequently, for the samples exceeding the guidance level of $0.5 \mathrm{~Bq} \mathrm{~L}^{-1}$ for alpha and respectively $1 \mathrm{~Bq}$ $\mathrm{L}^{-1}$ for gross beta activities, stipulated in WHO Guidelines for Drinking-water Quality [38], further investigations were carried out, by measuring ${ }^{210} \mathrm{Po}$ and ${ }^{40} \mathrm{~K}$ specific activities. In some cases, when the residue mass of the sample permitted further investigations to be performed, ${ }^{210} \mathrm{Po}$ was also measured for samples with activities below WHO guidance level for gross alpha.

Gross alpha activities (excluding ${ }^{222} \mathrm{Rn}$ ), which are presented in Fig. 2, ranged between $21 \pm 2$ and $2440 \pm 210 \mathrm{mBq}$ $\mathrm{L}^{-1}$ for the samples collected in Covasna and Harghita (CVHR), and between $40 \pm 6$ and $7530 \pm 658 \mathrm{mBq} \mathrm{L}^{-1}$ for those from Bistrița-Năsăud and Maramureș (BNMM). 26.7\% of samples exceeded the guidance level of $500 \mathrm{mBq} \mathrm{L}^{-1}$ stated in WHO, 2017 for alpha activity, and 53.5\% exceeded the Romanian legislation threshold of $100 \mathrm{mBq} \mathrm{L}^{-1} .12 \mathrm{sam}$ ples had activities under the detection limit $\left(<20 \mathrm{mBq} \mathrm{L}^{-1}\right)$, and an additional 8 samples could not be measured for gross alpha activity, due to insufficient residue. Therefore, these samples were only measured for gross alpha and beta (total) activity.

Gross beta activities ranged between $50 \pm 3$ and $4160 \pm 398 \mathrm{mBq} \mathrm{L}^{-1}$ for CVHR samples, and between $40 \pm 3$ and $5520 \pm 430 \mathrm{mBq} \mathrm{L}^{-1}$ for BNMM. A total $26 \%$ of the samples exceeded the guidance level of $1000 \mathrm{mBq} \mathrm{L}^{-1}$ (stated in both law 301/2015 and WHO, 2017), and 13 samples were below the MDA of $25 \mathrm{mBq} \mathrm{L}^{-1}$. Subsequently, as guidelines are indicating, ${ }^{40} \mathrm{~K}$ measurements were performed for the samples exceeding the recommended level for gross beta. The potassium activities are radiologically negligible, due to the age-dependent effective dose conversion factor for adults $\left(\mathrm{CF}_{\mathrm{K}-40}=6.2 \times 10^{-6} \mathrm{mSv} \mathrm{Bq}^{-1}\right)$, which is the least of the other radionuclides [12]. Thus, the ${ }^{40} \mathrm{~K}$ contribution should be extracted from the gross beta activity in order to accurately assess safety of drinking water [38]. ${ }^{40} \mathrm{~K}$ activities could be detected in 8 samples from BNMM. The activities ranged from $260 \pm 30$ to $4368 \pm 390 \mathrm{mBq} \mathrm{L}^{-1}$, with another 7 values under the detection limit. The gross beta activities and ${ }^{40} \mathrm{~K}$ contribution are presented in Fig. 3. It can be observed that after ${ }^{40} \mathrm{~K}$ subtraction, gross beta activities of three samples decreased under the guideline level.

Radon $\left({ }^{222} \mathrm{Rn}\right)$ is not regulated by WHO Guidelines for Drinking-water Quality, 2017, as 90\% of the dose attributable to radon in drinking-water comes from inhalation rather than ingestion [37]. Thus, controlling the inhalation pathway is the most effective way to control radon internal exposure [38]. Romanian law 301/2015 imposes a recommended value of $100 \mathrm{~Bq} \mathrm{~L}^{-1}$ for ${ }^{222} \mathrm{Rn}$ in drinking water. However, radon in not to be included in the gross alpha activity of the samples. The ${ }^{222} \mathrm{Rn}$ activity values ranged between $0.6 \pm 0.08$ and $81 \pm 6 \mathrm{~Bq} \mathrm{~L}^{-1}$ for the whole set of samples, and did not exceed the national legislation recommendations.

Radium $\left({ }^{226} \mathrm{Ra}\right)$ is one of the most dangerous and widely distributed long-lived $\alpha$-emitters found in environmental samples [31] due to a combination of its long half-life $\left(T_{1 / 2}=1602\right.$ years) and radiological effects [1]. In the present study, the ${ }^{226} \mathrm{Ra}$ specific activities ranged between $21 \pm 1$ and $429 \pm 40 \mathrm{mBq} \mathrm{L}^{-1}$ for CVHR and between $24 \pm 2$ and $1154 \pm 112 \mathrm{mBq} \mathrm{L}^{-1}$ for BNMM area. Only one sample has exceeded the WHO guidance level of $1000 \mathrm{mBq} \mathrm{L}^{-1}$ and 5 that of national legislation, which is $500 \mathrm{mBq} \mathrm{L}^{-1} .35 \mathrm{sam}$ ples had activities under the detection limit $\left(<20 \mathrm{mBq} \mathrm{L}^{-1}\right)$. ${ }^{226} \mathrm{Ra}$ activity values and their compliance with the guidance level can be observed in Fig. 4.

Furthermore, the annual effective doses (AED) were calculated in order to assess ${ }^{226} \mathrm{Ra}$ contribution to the received dose, resulting from water ingestion. The recommended maximum value for AED attributed to drinking water, considering a daily consumption of $2 \mathrm{~L}$, is $0.1 \mathrm{mSv} \mathrm{yr}^{-1}[21,38]$. For the calculation, the national legislation dose coefficient (CF) of $2.8 \cdot 10^{-7} \mathrm{~Sv} \cdot \mathrm{Bq}^{-1}$ was considered. The values are presented in Fig. 5, and ranged from 0.002 to $0.23 \mathrm{mSv} \mathrm{yr}^{-1}$, with 5 samples exceeding the guidance value.

Polonium $\left({ }^{210} \mathrm{Po}\right)$ activities were generally low, ranging between $18 \pm 2$ and $64 \pm 5 \mathrm{mBq} \mathrm{L}^{-1}$, with only 4 samples exceeding the minimum detectable activity, and 32 being below it $\left(<15 \mathrm{mBq} \mathrm{L}^{-1}\right)$. The activities did not exceed, in any case, the guidance level for ${ }^{210} \mathrm{Po}$, which is $100 \mathrm{mBq}$ $\mathrm{L}^{-1}$, adopted by both $\mathrm{WHO}$ and Romania.

\section{Data analysis}

The relationships between gross alpha, gross beta and ${ }^{226} \mathrm{Ra}$ specific activities with water physico-chemical parameters ( $\mathrm{T}, \mathrm{pH}, \mathrm{ORP}$, conductivity, TDS and salinity) were investigated by performing Pearson's correlations, and the results 

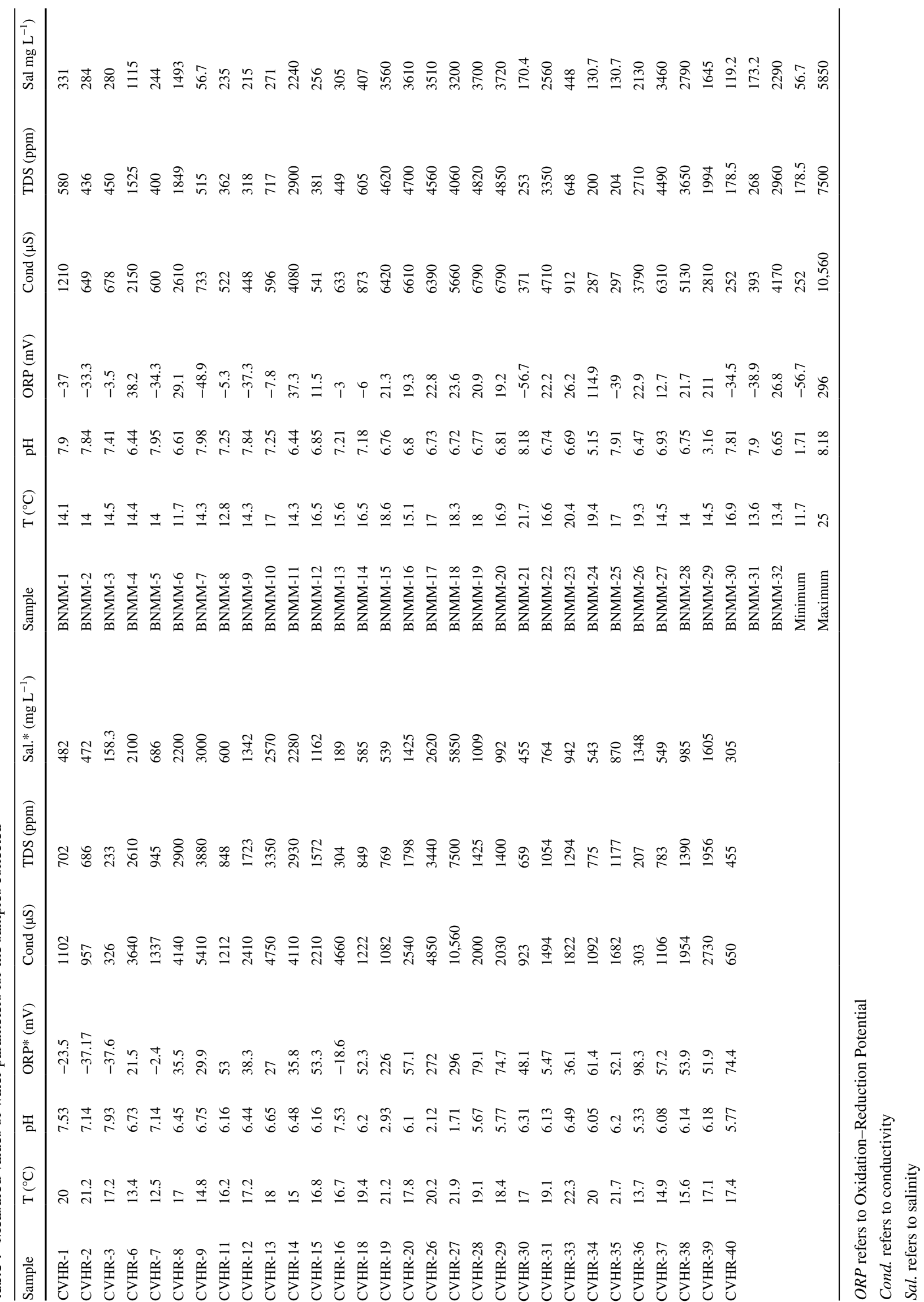


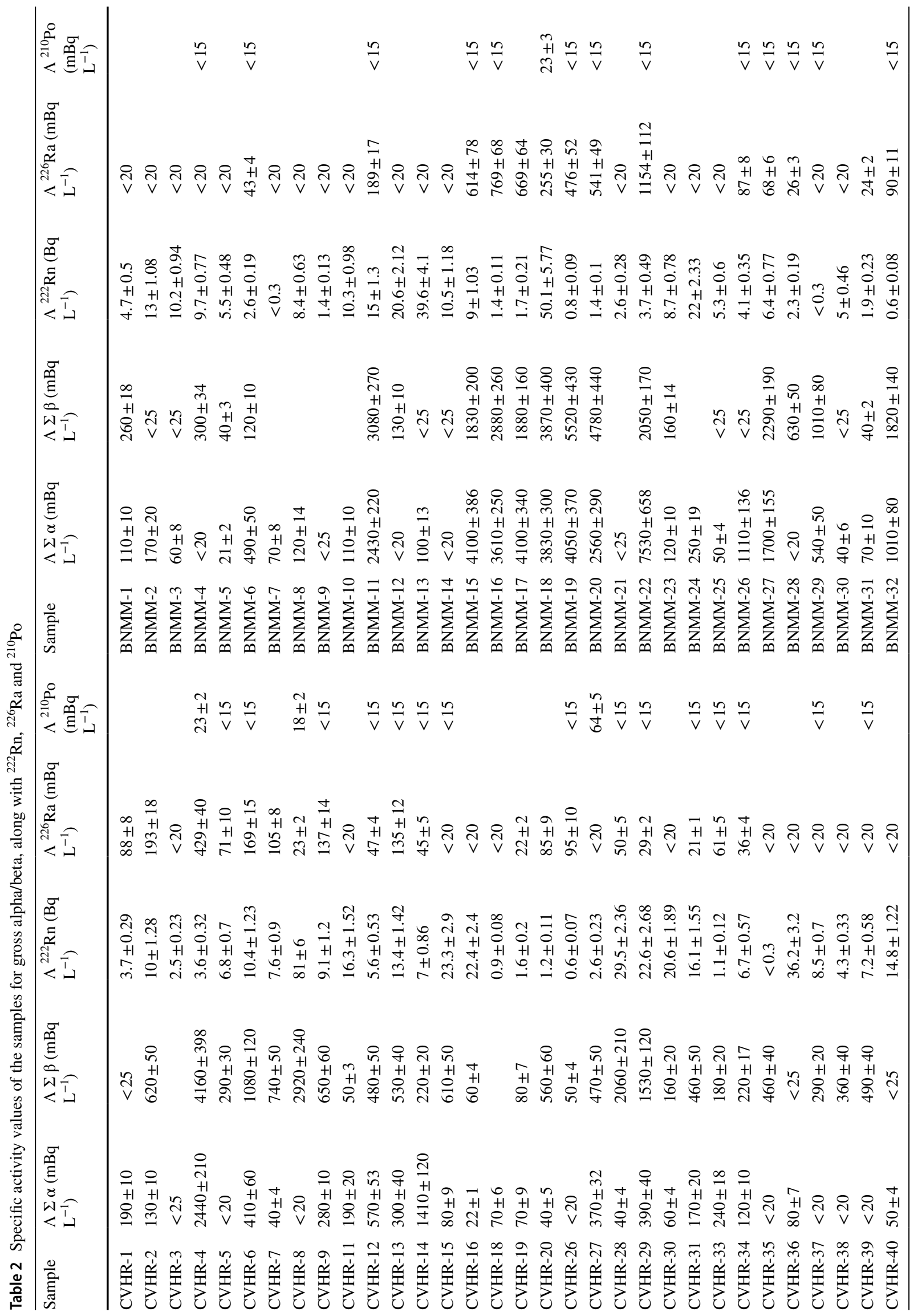


Fig. 2 Gross alpha specific water samples in distinction to national and international guidance levels activity values of the examined

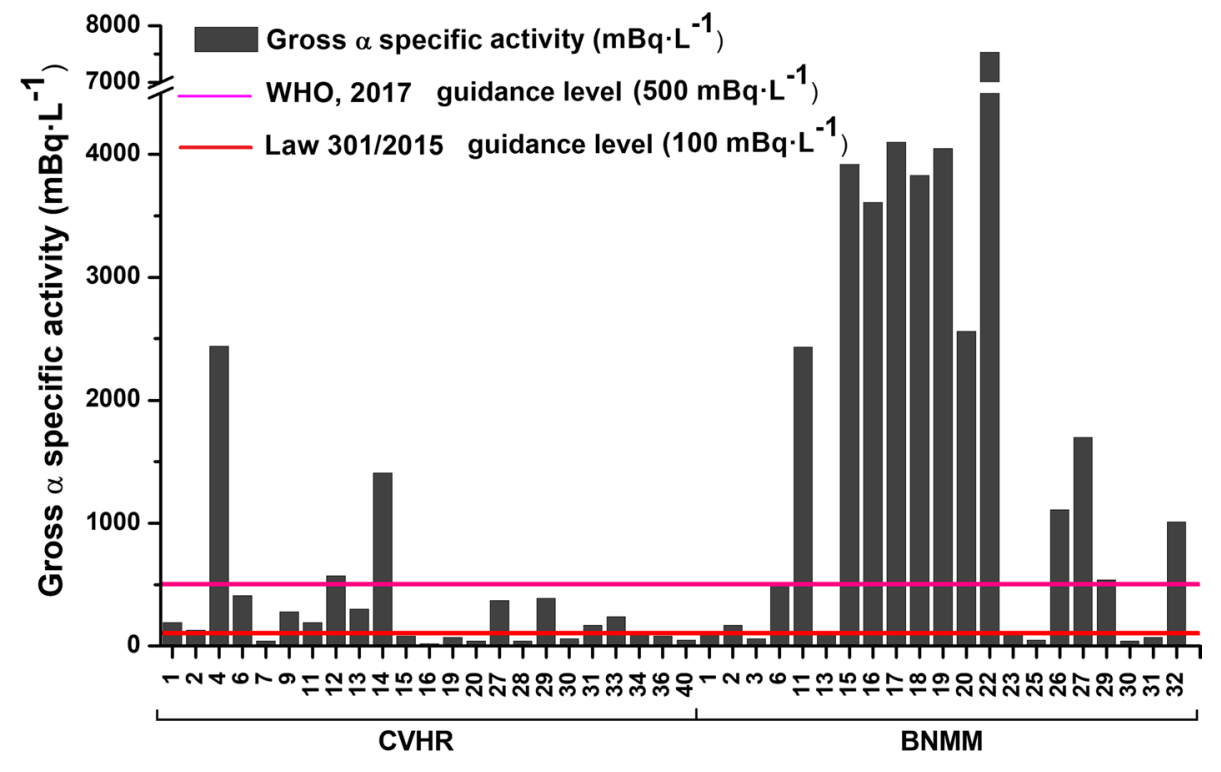

Fig. 3 Gross beta specific activity values of the examined water samples in distinction to the common national and international guidance level

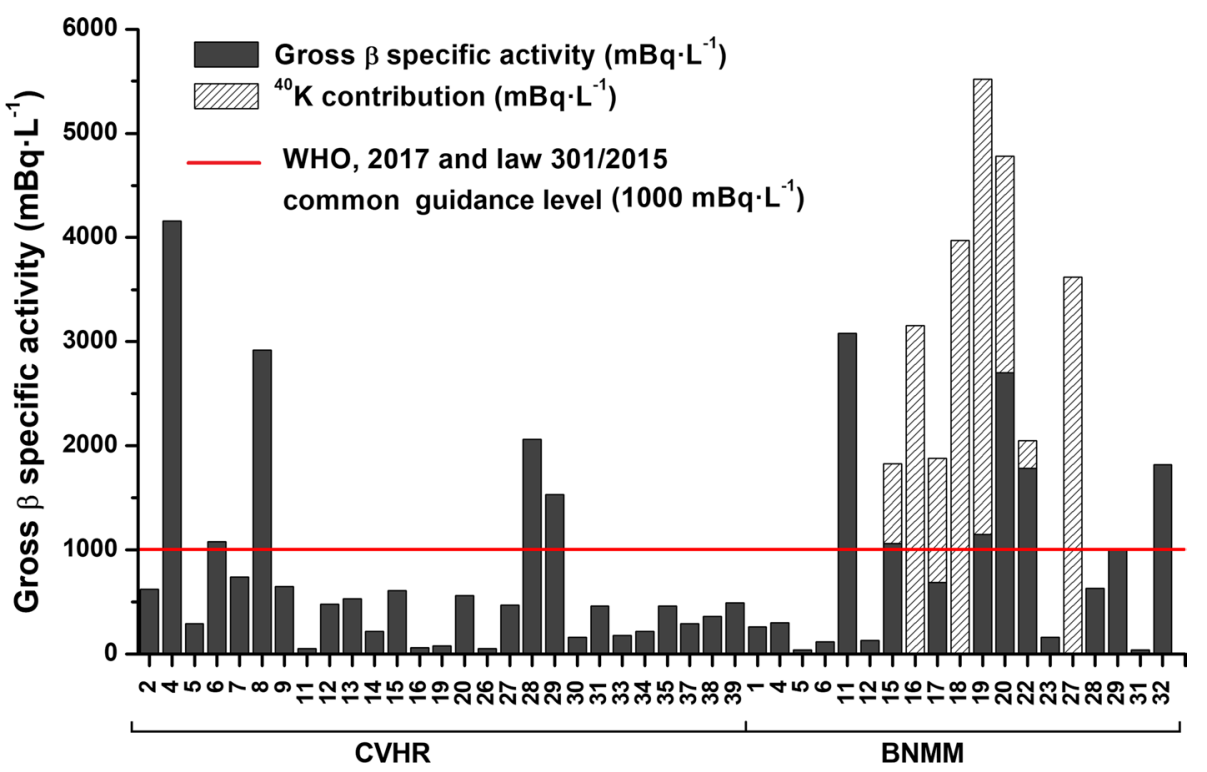

are presented in Table 3. Significant positive correlations can be observed between specific activities and salinity, with a correlation coefficient of $R=0.62$ for $\alpha$ and $R=0.59$ for $\beta$ and ${ }^{226} \mathrm{Ra}$, considering a confidence interval of $\alpha=0.01$. Other authors have previously observed such relationships between salinity and dissolved radium [19, 20], which could imply ion-exchange dynamics. As salinity and conductivity are related (both measures being increased by dissolved ions), the positive correlations between gross alpha, beta as well as radium activities and conductivity are expected ( $R=0.60$ for $\alpha ; 0.57$ for $\beta ; 0.59$ for ${ }^{226} \mathrm{Ra}, \alpha=0.01$ ). Another positive correlation can be established between specific activities and TDS ( $\mathrm{R}=0.63$ for $\alpha$ and $R=0.59$ for $\beta$ and $\left.{ }^{226} \mathrm{Ra}, \alpha=0.01\right)$. In literature, [32] also noticed positive correlations between TDS and uranium, as well as [27], who found similar relationships for ${ }^{226} \mathrm{Ra}$ and ${ }^{228} \mathrm{Ra}$. TDS, salinity and conductivity have similar $R$ values when correlated to gross alpha, beta and radium activities, which is the result of the strong correlations between these parameters alone. Additionally, no correlations could be settled between the activity of the samples and temperature, $\mathrm{pH}$ or oxidation-reduction potential, implying that these parameters do not affect radionuclide concentrations in water.

For a better representation and understanding of the activity values, the frequency distributions of gross alpha and beta specific activities were analyzed (Fig. 6). First, an initial distribution revealed that the highest number of cases are contained in the first class interval (between 0 and $1000 \mathrm{mBq} \mathrm{L}^{-1}$ ) for both alpha and beta activities, representing $77 \%$ of gross alpha, respectively $71 \%$ of gross beta 
Fig. $4{ }^{226}$ Ra specific activity values of the examined water samples in distinction to national and international guidance level
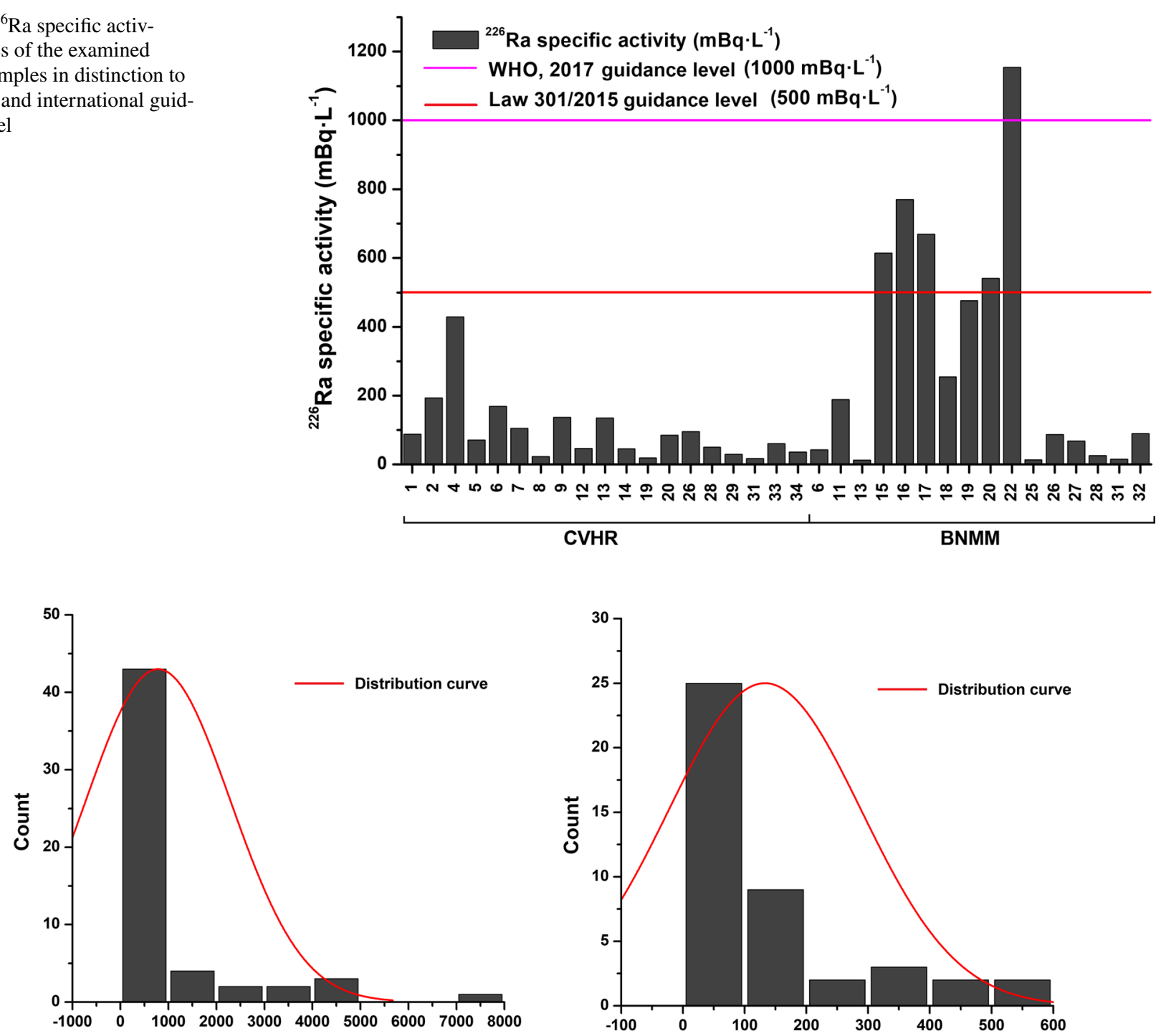

A Gross alpha specific activity intervals $\left(\mathrm{mBq} \cdot \mathrm{L}^{-1}\right)$

B Gross alpha specific activity intervals $\left(\mathrm{mBq} \cdot \mathrm{L}^{-1}\right)$
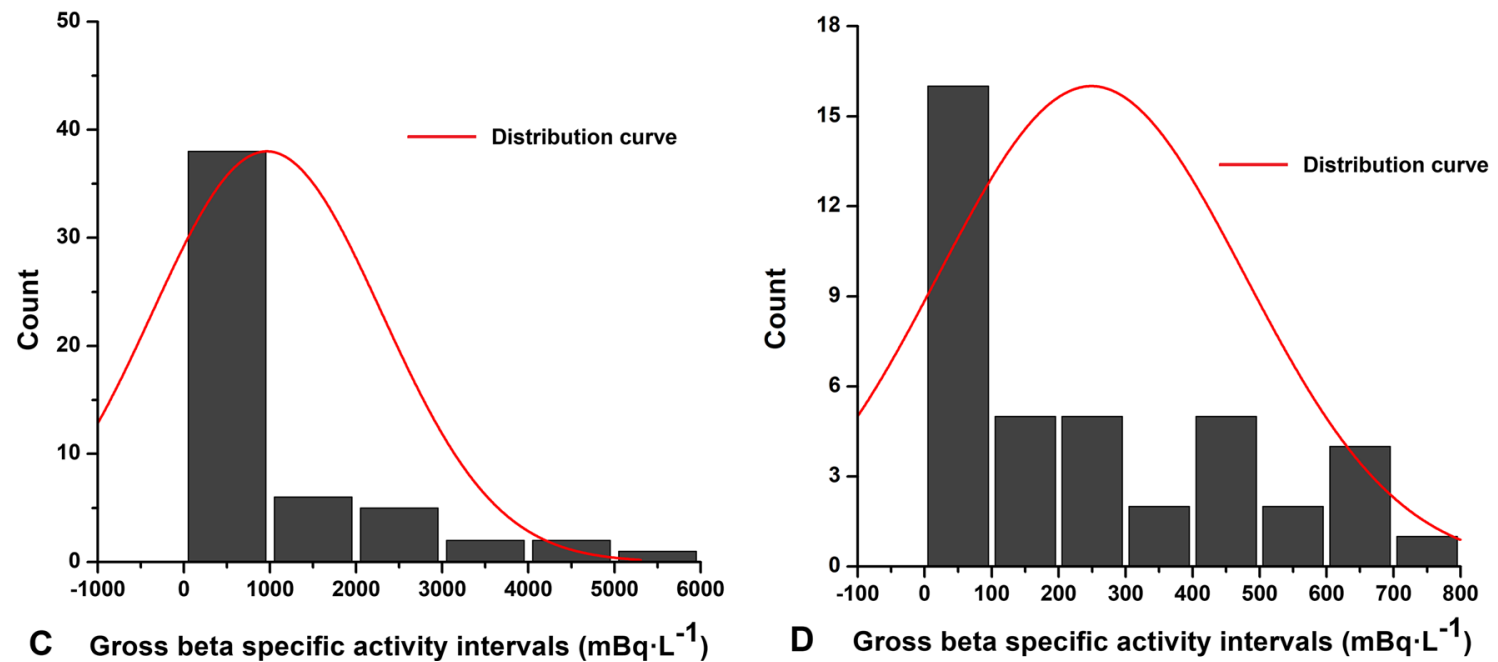

C Gross beta specific activity intervals $\left(\mathrm{mBq} \cdot \mathrm{L}^{-1}\right)$

Fig. 5 Annual effective doses (AED) attributed to ${ }^{226}$ Ra activities, in distinction to the reference dose established by Romanian law $301 / 2015$ 
Table 3 Pearson's correlations between water parameters and gross alpha, beta, and ${ }^{226} \mathrm{Ra}$ specific activities of the samples

\begin{tabular}{|c|c|c|c|c|c|c|c|c|c|}
\hline & $\Lambda \Sigma \alpha$ & $\Lambda \Sigma \beta$ & $\Lambda{ }^{226} \mathrm{Ra}$ & $T$ & $\mathrm{pH}$ & ORP & Conductivity & TDS & Salinity \\
\hline$\Lambda \Sigma \alpha$ & 1.00 & 0.68 & 0.91 & -0.004 & 0.07 & -0.06 & 0.60 & 0.63 & 0.62 \\
\hline$\Lambda \Sigma \beta$ & & 1.00 & 0.52 & -0.03 & 0.14 & -0.13 & 0.57 & 0.59 & 0.59 \\
\hline$\Lambda{ }^{226} \mathrm{Ra}$ & & & 1.00 & -0.02 & 0.14 & -0.12 & 0.59 & 0.59 & 0.59 \\
\hline $\mathrm{T}$ & & & & 1.00 & -0.26 & 0.24 & 0.16 & 0.16 & 0.15 \\
\hline $\mathrm{pH}$ & & & & & 1.00 & -0.99 & -0.21 & -0.23 & -0.25 \\
\hline ORP & & & & & & 1.00 & 0.22 & 0.24 & 0.26 \\
\hline Conductivity & & & & & & & 1.00 & 0.98 & 0.97 \\
\hline TDS & & & & & & & & 1.00 & 0.99 \\
\hline Salinity & & & & & & & & & 1.00 \\
\hline
\end{tabular}

Highlighted in italics - relevant correlations for $\alpha=0.01$ confidence interval
Fig. 6 Frequency distribution of gross alpha and beta specific activities Panel (a) represents the gross alpha frequency distribution for the whole set of samples; panel (b) represents a focused gross alpha frequency distribution on the $0-1000 \mathrm{mBq}$ $\mathrm{L}^{-1}$ interval; panel (c) represents the gross beta frequency distribution for the whole set of samples; panel (d) represents a focused gross beta frequency distribution on the $0-1000 \mathrm{mBq}$ $\mathrm{L}^{-1}$ interval

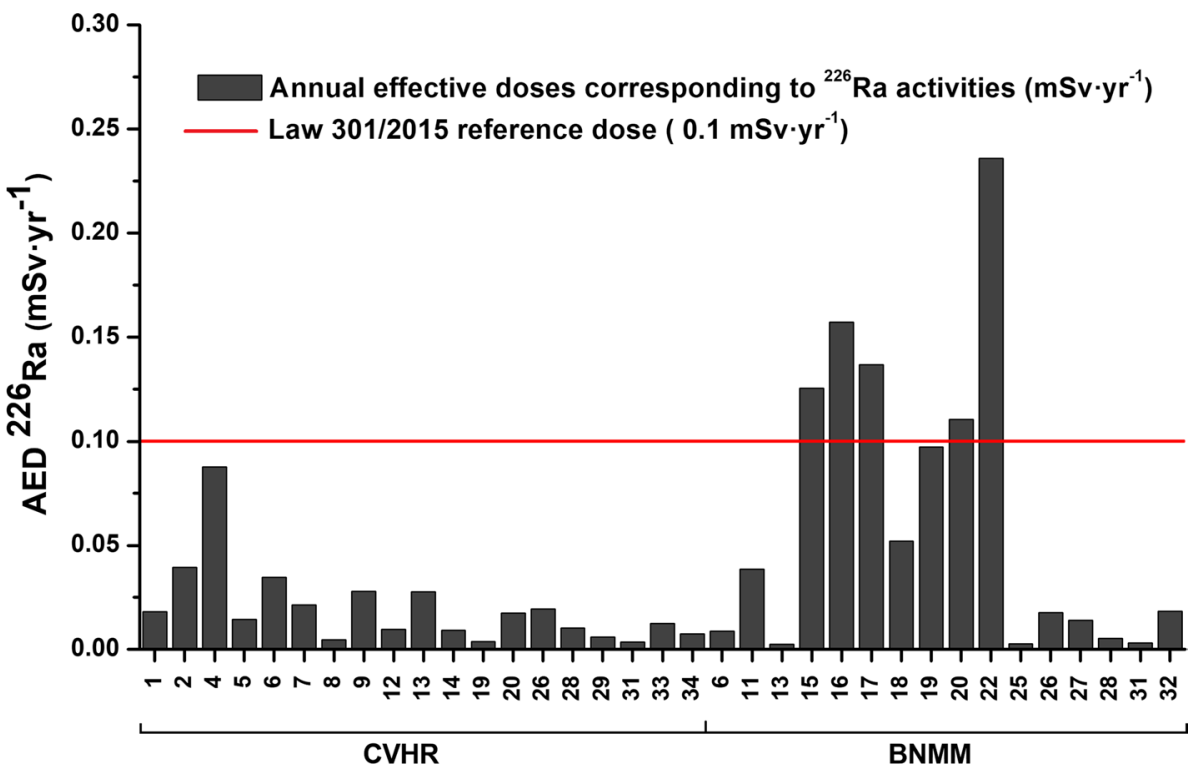

values from the total set of samples (Fig. 6, panels A and C). The higher class intervals showed a reduced frequency. Considering this observation, further statistical analyses were performed for an in-depth look at this specific class interval. As such, a second frequency distribution performed on the values in the $0-1000 \mathrm{mBq} \mathrm{L}^{-1}$ range highlighted that the highest number of cases are present in the $0-100 \mathrm{mBq} \mathrm{L}^{-1}$ range, with $46 \%$ of the total samples for gross alpha activities, respectively $29 \%$ of the gross beta activities (Fig. 6, panels $\mathrm{C}$ and D) being contained in it. From the frequency distributions presented, it can be concluded that both gross alpha and beta activities are falling mostly in the low activity class intervals, and the cases are exponentially decreasing with activity.

For an enhanced visual representation of the specific activity data, a spatial distribution map was constructed, displaying the location of the samples and their corresponding gross alpha, beta and ${ }^{226}$ Ra activity values (Fig. 7). It can be observed that Bistrița-Năsăud (BN) county hosts the highest activity samples for all three parameters, clustered in a"hotspot" area, near Sângeorz-Băi town. The highlighted area includes the samples labeled BNMM 15-20, and 22, which are among the highest activity samples in the dataset, and are also exceeding the guidance levels set by national legislation. An explanation for the cluster formation is that the springs are closely located and similar in water physicochemical parameters values, and thus could be sourced from the same underground aquifer. In contrast, the other studied areas generally showed low specific activities, with sporadically occurrences of higher concentration values and no distinguishable patterns or hotspots.

Furthermore, a comparison between the results obtained in the present study for gross alpha and beta activities and the results of other similar studies in literature has been performed (Table 4). It can be observed that, except for [2], in Jordan, the present study has higher mean values for the gross alpha/beta activities, as well as maximum values, in comparison to the other studies cited. The difference in values between the results of [28] in Galați county, Romania, and the results of the present work could be explained by the 
A Gross alpha activities
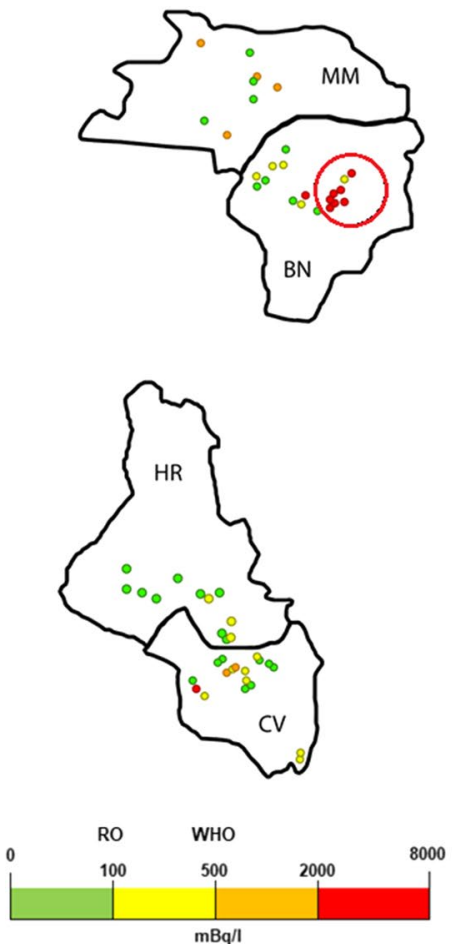

B Gross beta activities
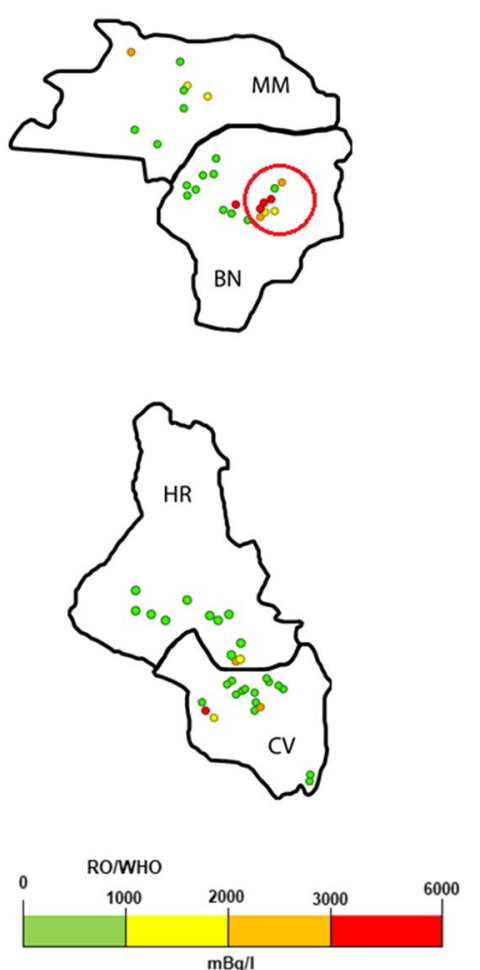

C ${ }^{226}$ Ra activities
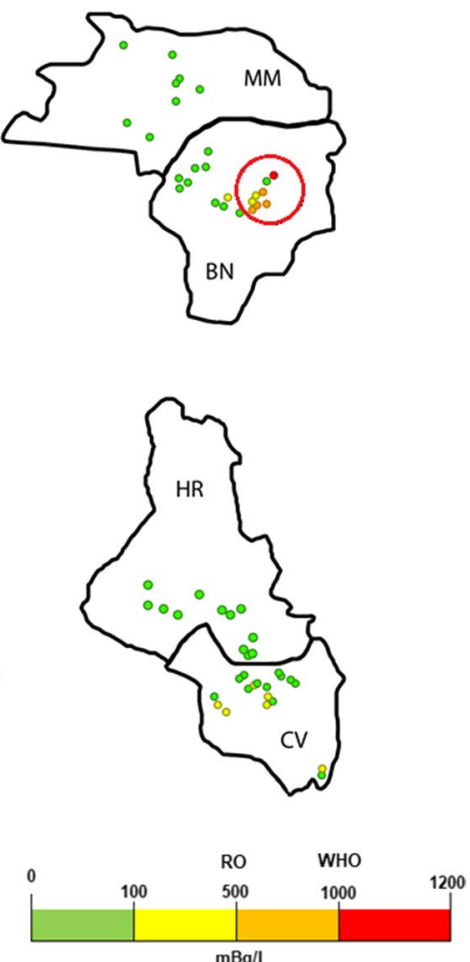

Fig. 7 Spatial distribution of the samples and their corresponding gross alpha (panel a), gross beta (panel b) and ${ }^{226}$ Ra (panel c) specific activity values; RO refers to the Romanian legislation 301/2015 guidance level, WHO refers to WHO, 2017 guidance level

Table 4 Gross alpha/beta specific activities comparison between the present study and other studies conducted in different countries/regions

\begin{tabular}{lllllll}
\hline Area and country & \multicolumn{2}{l}{$\Sigma \alpha\left(\mathrm{Bq} \mathrm{L}^{-1}\right)$} & & \multicolumn{2}{l}{$\Sigma \beta\left(\mathrm{Bq} \mathrm{L}^{-1}\right)$} & References \\
\cline { 2 - 3 } & Mean & Range & & Mean & Range & \\
\hline Galați/Romania & 0.022 & $<0.06-0.852$ & & 0.076 & $<0.025-0.435$ & {$[28]$} \\
Hungary & 0.189 & $0.035-1.749$ & & 0.209 & $0.033-2.105$ & {$[15]$} \\
Serbia & & $0.001-0.013$ & & $0.041-0.173$ & {$[14]$} \\
Jordan & 1.57 & $0.18-9.46$ & & 1.62 & $0.36-7.48$ & {$[2]$} \\
Turkey & 0.192 & $0.080-0.380$ & & 0.579 & $0.120-3.470$ & {$[36]$} \\
Nigeria & & $0.080-2.300$ & & $0.120-4.970$ & {$[26]$} \\
Southern Vietnam & 0.183 & $0.024-0.748$ & & 0.152 & $0.027-0.632$ & {$[12]$} \\
Italy & & $<0.008-0.186$ & & $<0.048-0.150$ & {$[11]$} \\
Eastern Carpathians /Romania & 1.033 & $<0.020-7.530$ & & 1.140 & $<0.025-5.520$ & Present study \\
\hline
\end{tabular}

geology of the study site. The Neogene volcanic mountain ranges that are located close to the study site could influence the values and lead to higher activities, as radioactivity concentration in soil is relatively higher in areas with volcanic rocks [35]. Beside geology, the high specific activity cluster located in Bistrița-Năsăud county has considerably raised the mean values for both gross alpha and beta, as well as the maximum values.

\section{Conclusions}

Sixty-four carbonated water samples collected from natural springs were analysed from a radiological perspective, in order to evaluate their compliance with national [21] and international [38] guidance levels for radioactivity in drinking water. Initial gross alpha and beta specific activity measurements revealed that for alpha activities, 
26.7\%, of the samples exceeded the WHO, 2017 guidance level of $500 \mathrm{mBq} \mathrm{L}^{-1}$, and $53.5 \%$ exceeded the Romanian law threshold of $100 \mathrm{mBq} \mathrm{L}^{-1}$. Gross beta common recommended value of $1000 \mathrm{mBq} \mathrm{L}^{-1}$ was exceeded by $26 \%$ of the samples. However, frequency distribution analyses indicated that the activities for both gross alpha and beta are generally in the lower distribution intervals $\left(0-1000 \mathrm{mBq} \mathrm{L}^{-1}\right)$, and the frequency decreases exponentially with activity. ${ }^{226} \mathrm{Ra}$ activity values exceeded the national guideline level by five samples $\left(500 \mathrm{mBq} \mathrm{L}^{-1}\right)$, of which one was above $1000 \mathrm{mBq} \mathrm{L}^{-1}$ (WHO recommended value). The highest values from the dataset for gross alpha, beta and radium-226 are concentrated in a hotspot area composed of 7 samples, in Bistrița-Năsăud county. Polonium-210 specific activities were low and did not exceed the guidance levels. After calculating the Annual Effective Dose (AED) attributable to radium-226, five samples had a value above the reference dose of $0.1 \mathrm{mSv} \mathrm{yr}^{-1}$. The mean and maximum values for specific activities for gross alpha/ beta were generally higher than those found in other studies, which could be attributed to the presence of volcanic rocks in the study area, and the post-volcanic emanations associated with the adjacent Neogene volcanic range. The guidance levels, the dose coefficients and the AED calculations performed considered a water consumption rate of $2 \mathrm{~L} /$ day for the investigated spring waters. Daily consumption from springs exceeding guidance levels should be avoided, and not used as a primary source of drinking water. Being the first investigation performed on the post-volcanic region of Romania, and one of the few conducted in the country, the present work reveals an insight regarding the quality and radiological properties of the natural mineral water sources in this region. By assessing the compliance of the specific activity values of the samples with the recommendations contained in international and national guidelines, the present study provides useful information regarding public health safety. The high percentage of samples exceeding the recommended values for the investigated parameters highlights the importance of studying potable natural water from a radiological perspective.

Acknowledgements We acknowledge the financial support from "Babes-Bolyai" University, Cluj-Napoca, which provided a scientific scholarship. We acknowledge the financial support from EEA and Norway Grants , EEA-RO-NO-2018-0126, 3/2019.

Funding Open access funding provided by University of Pannonia. The funding sources had no involvement in study design; collection, analysis and interpretation of data; writing of the report or in the decision to submit the article for publication.

Open Access This article is licensed under a Creative Commons Attribution 4.0 International License, which permits use, sharing, adaptation, distribution and reproduction in any medium or format, as long as you give appropriate credit to the original author(s) and the source, provide a link to the Creative Commons licence, and indicate if changes were made. The images or other third party material in this article are included in the article's Creative Commons licence, unless indicated otherwise in a credit line to the material. If material is not included in the article's Creative Commons licence and your intended use is not permitted by statutory regulation or exceeds the permitted use, you will need to obtain permission directly from the copyright holder. To view a copy of this licence, visit http://creativecommons.org/licenses/by/4.0/.

\section{References}

1. Al-Masri MS, Blackburn R (1995) Radiochemical determination of 226Ra using Cerenkov counting. J Radioanal Nucl Chem 196(2):339-344. https://doi.org/10.1007/bf02038053

2. Alomari AH, Saleh MA, Hashim S, Alsayaheen A, Abdeldin I, Banikhalaf R (2019) Measurement of gross alpha and beta activity concentration in groundwater of Jordan: groundwater quality, annual effective dose and lifetime risk assessment. J Water Health 17(6):957-970. https://doi.org/10.2166/wh.2019. 158

3. Bányai J. (1934) The mineral waters from Szeklerland. Kül. Erdélyi Múzeum, XXXIX, 13 (in Hungarian)

4. Begy R. C., Dreve S., Gabor A. T., Rusu O. A., Cosma, C. (2012) Measurements of radium content in some spring waters from Romania. Environ. Eng. Manag. J., 11(2), 247-251. https://doi.org/10.30638/eemj.2012.031

5. Begy RC, Dumitru OA, Simon H, Steopoaie I (2015) An improved procedure for the determination of 210Po by alpha spectrometry in sediments samples from Danube Delta. J Radioanal Nucl Chem. https://doi.org/10.1007/s10967-014-3703-Z

6. Berszán I, Jánosi Cs, Jánosi K, Kristály F, Péter É, Szakáll S, Ütő G (2009) Székelyföld ásványvizei, Polgár-Társ Alapítvány, Csíkszereda, 239 (in Hungarian)

7. Cfarku F, Xhixha G, Bylyku E, Zdruli P, Mantovani F, Përpunja F, Callegari I, Guastaldi E, Xhixha KM, Thoma H (2014) A preliminary study of gross alpha/beta activity concentrations in drinking waters from Albania. J Radioanal Nucl Chem 301(2):435-442. https://doi.org/10.1007/s10967-014-3142-x

8. Dimitriu RI, Bulai M, Minea I (2014) Mineral groundwater resources and health tourism in the Eastern Carpathians (Romania). In: 14th International Multidisciplinary Scientific GeoConference SGEM, 3(1),pp 463-470

9. European Commission (EC) Council directive 98/83/EC of 3 November 1998 on the quality of water intended for human consumption

10. Feru A. (2012) Guide to natural mineral waters, Societatea Națională a Apelor Minerale, București, 105 (in Romanian)

11. Forte M, Rusconi R, Cazzaniga MT, Sgorbati G (2007) The measurement of radioactivity in Italian drinking waters. Microchem J 85(1):98-102. https://doi.org/10.1016/j.microc.2006.03. 004

12. Ho PL, Hung LD, Minh VT, Chinh DV, Thanh TT, Tao CV (2020) Simultaneous determination of gross alpha/beta activities in groundwater for ingestion effective dose and its associated public health risk prevention. Sci Rep, 10(1) https://doi. org/10.1038/s41598-020-61203-y

13. International Atomic Energy Agency (IAEA) (Ed.) (2016) Criteria for radionuclide activity concentrations for food and drinking water

14. Janković MM, Todorović DJ, Todorović NA, Nikolov J (2012) Natural radionuclides in drinking waters in Serbia. Appl Radiat Isot 70(12):2703-2710. https://doi.org/10.1016/j.apradiso.2012. 08.013 
15. Jobbágy V, Kávási N, Somlai J, Dombovári P, Gyöngyösi C, Kovács T (2011) Gross alpha and beta activity concentrations in spring waters in Balaton Upland. Hungary Radiat Meas 46(1):159-163. https://doi.org/10.1016/j.radmeas.2010.08.004

16. Nikolov J, Stojković I, Todorović N, Tenjović B, Vuković S, Knežević J (2018) Evaluation of different LSC methods for 222Rn determination in waters. Appl Radiat Isot 142:56-63. https://doi.org/10.1016/j.apradiso.2018.09.013

17. Kis B-M, Baciu C, Zsigmond A-R, Kékedy-Nagy L, Kármán K, Palcsu L, Máthé I, Harangi S (2020) Constraints on the hydrogeochemistry and origin of the $\mathrm{CO} 2$-rich mineral waters from the Eastern Carpathians-Transylvanian Basin boundary (Romania). J Hydrol 591:125311. https://doi.org/10.1016/j. jhydrol.2020.125311

18. Kis B-M, Baciu C, Ladislau KN (2013) A statistical approach to the mineral waters of transylvanian basin-eastern Carpathians boundary. STUDIA UBB AMBIENTUM, LVIII 1-2:55-63

19. Kraemer TF, Reid DF (1984) The occurrence and behavior of radium in saline formation water of the U.S. Gulf Coast region. Chem Geol 46(2):153-174. https://doi.org/10.1016/00092541(84)90186-4

20. Lauria DC, Godoy JM (2002) Abnormal high natural radium concentration in surface waters. J Environ Radioact 61(2):159-168. https://doi.org/10.1016/s0265-931x(01)00123-0

21. Law no. 301 of November 27, 2015 on the establishment of requirements for the public health safety with regard to radioactive substances in drinking water issued by the Romanian parliament, published in the Official Gazette no. 904 of December 7, 2015

22. Leaney FW, Herczeg AL (2006) A rapid field extraction method for determination of radon-222 in natural waters by liquid scintillation counting. Limnol Oceanogr-Meth 4(7):254-259. https://doi. org/10.4319/lom.2006.4.254

23. Missimer TM, Teaf C, Maliva RG, Danley-Thomson A, Covert D, Hegy M (2019) Natural radiation in the rocks, soils, and groundwater of southern Florida with a discussion on potential health impacts. Int J Environ Res Public Health 16(10):1793. https://doi. org/10.3390/ijerph16101793

24. Moldovan M, Benea V, Ni DC, Papp B, Burghele BD, BicanBrișan N, Cosma C (2014) Radon and radium concentration in water from North-West of Romania and the estimated doses. Radiat Prot Dosimetry 162(1-2):96-100. https://doi.org/10.1093/ $\mathrm{rpd} / \mathrm{ncu} 230$

25. Moldovan M, Cosma C, Horvath Z, Sferle T (2010) Radon and radium concentrations in water from Transylvania and the assessment of the resulting dose. Annals of the West University of Timisoara. Physics Series, Timisoara 54:69-76

26. Muhammad BG, Jaafar MS, Akpa TC (2010) A survey of gross alpha and beta activity concentrations in groundwater from Katsina area of Northern Nigeria. Radiat Prot Dosimetry 141(2):127133. https://doi.org/10.1093/rpd/ncq162

27. Nguyen DC, Nowak J (2021) Natural radioactivity in thermal waters: a case study from Poland. Energies 14(3):541. https:// doi.org/10.3390/en14030541
28. Pintilie V, Ene A, Georgescu LP, Morar L, Iticescu C (2016) Measurements of gross alpha and beta activity in drinking water from Galati region. Romania Rom Rep Phys 68(3):1208-1220

29. Pintilie-Nicolov V, Georgescu P, Iticescu C, Moraru D, Pintilie A (2020) The assessment of the annual effective dose due to ingestion of radionuclides from drinking water consumption: calculation methods. J Radioanal Nucl Chem 327(1):49-58. https://doi. org/10.1007/s10967-020-07438-5

30. Pricajan A (1972) Apele minerale și termale din România. Ed. Tehnica, București (in Romanian)

31. Sill CW (1987) Determination of radium-226 in ores, nuclear wastes and environmental samples by high-resolution alpha spectrometry. Nucl Chem Waste Manage 7(3-4):239-256. https://doi. org/10.1016/0191-815x(87)90069-6

32. Singh S, Rani A, Mahajan RK, Walia TPS (2003) Analysis of uranium and its correlation with some physico-chemical properties of drinking water samples from Amritsar. Punjab J Environ Monit 5(6):917. https://doi.org/10.1039/b309493f

33. Suomela J (1993) Method for determination of radon - 222 in water by liquid scintillation counting. SSI-rapport 93-13, ISSN: 0282-4434, https://inis.iaea.org/collection/NCLCollectionStore/_ Public/25/011/25011271.pdf .

34. Szakács A (2009) Post-volcanic Phenomena in the East Carpathians. In Natural Heritage from East to West (87-93). Springer, Heidelberg. https://doi.org/10.1007/978-3-642-01577-9_10

35. Tolluoğlu AÜ, Eral M, Aytaş Ş, Akyilerentürk S, Işik MA, Aslani MA et al (2004) Relationship between natural radioactivity and rock types in Van Lake Basin-Turkey . International Symposium INSINUME 2004 in Situ-Nuclear Metrology as a Tool for Radioecology, Radioprotection of Environment, 19-25, Albena, Bulgaria

36. Turhan Ş, Özçıtak E, Taşkın H, Varinlioğlu A (2013) Determination of natural radioactivity by gross alpha and beta measurements in ground water samples. Water Res 47(9):3103-3108. https://doi. org/10.1016/j.watres.2013.03.030

37. UNSCEAR (2000) Report: Sources, effects and risks of ionizing radiation. New York, NY, United Nations. United Nations Scientific Committee on the Effects of Atomic Radiation (http://www. unscear.org/unscear/en/publications/2000_1.html)

38. World Health Organization (WHO) (2017) Guidelines for drinking-water quality 4ed Ch. 9, 203-218. WHO publications, Geneva.

Publisher's Note Springer Nature remains neutral with regard to jurisdictional claims in published maps and institutional affiliations. 